\title{
PENGARUH PROFITABILITAS, LIKUIDITAS, LEVERAGE, DAN UKURAN PERUSAHAAN TERHADAP RETURN SAHAM PADA PERUSAHAAN FOOD AND BEVERAGE
}

\author{
Ni Luh Putu Suryani Ulan Dewi ${ }^{1}$ \\ I Gede Mertha Sudiartha ${ }^{2}$ \\ ${ }^{1,2}$ Fakultas Ekonomi dan Bisnis Universitas Udayana, Bali, Indonesia \\ 1e-mail: luhsuryani04@gmail.com
}

\begin{abstract}
ABSTRAK
Tujuan penelitian ini adalah untuk mengetahui bagaimana pengaruh profitabilitas, likuiditas, leverage dan ukuran perusahaan terhadap return saham pada perusahaan food and beverage di BEI. Dalam penelitian ini variabel independen yang digunakan yaitu profitabilitas diukur dengan menggunakan return on asset (ROA), likuiditas diukur dengan menggunakan Current Ratio, leverage diukur dengan menggunakan Debt to Equity Ratio (DER) dan ukuran perusahaan diukur dengan menggunakan Ln (Size). Return Saham dalam penelitian ini digunakan sebagai variable dependen. Penelitian ini dilakukan pada perusahaan sektor food and beverage yang terdaftar di BEI tahun 2013-2016. Jumlah sampel yang diambil sebanyak 14 perusahaan, dengan metode purposive sampling, sehingga di dapat data pengamatan sebanyak 56. Teknik analisis data yang digunakan adalah analisis regresi linier berganda. Berdasarkan hasil penelitian menunjukkan bahwa leverage berpengaruh negatif signifikan pada return saham, sedangkan profitabilitas, likuiditas dan ukuran perusahaan berpengaruh positif signifikan pada return saham.
\end{abstract}

Kata kunci: profitabilitas, likuiditas, leverage, ukuran perusahaan, return saham

\begin{abstract}
The purpose of this study is to determine the effect of profitability, liquidity, leverage and size of the company to stock return on food and beverage companies in BEI. In this study the independent variables used are profitability measured by using return on assets (ROA), liquidity measured by using Current Ratio, leverage is measured by using Debt to Equity Ratio (DER) and firm size measured by using Ln (Size). Stock Return in this research is used as dependent variable. This study was conducted on food and beverage sector companies listed on the BEI in 2013-2016. The number of samples taken as many as 14 companies, with purposive sampling method, so that the data can be observed as much as 56. Data analysis techniques used are multiple linear regression analysis. Based on the results of the research shows that leverage has a significant negative effect on stock return, while profitability, liquidity and firm size have a significant positive effect on stock return.
\end{abstract}

Keywords: profitability, liquidity, leverage, firm size, stock return 


\section{PENDAHULUAN}

Pasar modal pada dasarnya merupakan pasar untuk sekuritas jangka panjang, seperti saham dan obligasi (Jones, 2006). Pasar modal memberikan hubungan antara pemilik dana (investor) dengan pengguna dana (emiten). Investor menggunakan pasar modal untuk keperluan investasi portofolionya dengan tujuan untuk mengumpulkan penghasilan. Perkembangan pasar modal menunjukkan ada keterbukaan dikalangan pemilik perusahaan untuk melakukan ekspansi demi perkembangan dan kelangsungan hidup perusahaan yang dimiliki.

Saat ini kesadaran masyarakat untuk berinvestasi semakin meningkat. Ada berbagai jenis investasi yang bisa dipergunakan salah satunya yaitu saham. Saham merupakan salah satu jenis investasi yang memberikan keuntungan yang besar tetapi memiliki resiko yang tinggi. Sebagai partner pemilik, segala keuntungan maupun kerugian akan dibagikan kepada pemegang saham atau investor. Penanaman modal dalam bentuk investasi saham (common stock) memerlukan suatu informasi yang akurat agar investor tidak dirugikan karena investasi pada saham di bursa efek merupakan investasi dengan suatu resiko yang relatif tinggi tetapi dengan keuntungan yang relatif tinggi pula. Kondisi yang buruk dari emiten akan berpengaruh kepada pendapatan bagi investor (return) yang berupa dividen tidak dibayarkan atau dibayar kurang atau bahkan menyebabkan harga saham mengalami penurunan dari harga beli semula (capital loss).

Return saham merupakan kelebihan harga jual saham diatas harga belinya. Semakin tinggi harga jual saham diatas harga beli, maka semakin tinggi investor memperoleh return. Bila investor menginginkan return yang tinggi maka investor 
harus menanggung resiko yang tinggi, dan sebaliknya bila menginginkan return yang rendah maka resiko yang ditanggung juga akan lebih rendah (Arista, 2012). Meningkat atau menurunnya return saham yang didapat para investor bisa ditentukan oleh kinerja keuangan perusahaan yang tercermin dalam laporan keuangan perusahaan. Malintan (2012) menyatakan untuk memprediksi return saham terdapat banyak faktor yang mempengaruhi dan menjadi tolak ukur investor, dimana salah satunya yaitu menilai kinerja keuangan perusahaan dalam menentukan saham yang akan dipilih. Bila kinerja keuangan perusahaan baik, akan membuat perusahaan sanggup membayar dividen kepada investor sehingga dapat meningkatkan perolehan return saham perusahaan.

Profitabilitas merupakan kemampuan perusahaan memperoleh laba atau ukuran efektifitas pengelolaan manajemen perusahaan (Wiagustini, 2010:77). Menurut Fahmi (2011:135) profitabilitas adalah mengukur efektivitas manajemen secara keseluruhan yang ditujukan oleh besar kecilnya tingkat keuntungan yang diperoleh dalam hubungannya dengan penjualan maupun investasi. Profitabilitas dapat dijadikan suatu gambaran bagaimana kemampuan perusahaan dalam pencapaian tujuannya (Raheem and Malik, 2013). Dalam penelitian ini profitabilitas diproksikan dengan return on asset (ROA). ROA mengukur kemampuan perusahaan untuk memperoleh laba dari aktiva yang digunakan (Sartono, 2010:123). Semakin tinggi ROA menunjukkan semakin efektif suatu perusahaan menggunakan aktivanya untuk menghasilkan laba bersih setelah pajak. Dengan meningkatnya ROA maka profitabilitas dari perusahaan semakin baik sehingga perusahaan mendapatkan return yang tinggi. Pernyataan ini 
didukung oleh hasil penelitian yang dilakukan oleh Daljono (2013), Haghiri (2012), Kabajeh et al. (2012) serta Har dan Ghafar (2015) bahwa ROA memiliki hubungan yang positif terhadap return saham.

Likuiditas adalah kemampuan perusahaan untuk memenuhi kewajiban finansial dalam jangka pendek dengan dana lancar yang tersedia (Wiagustini, 2010:76). Dalam penelitian ini likuiditas diproksikan dengan current ratio (CR). CR digunakan untuk mengetahui kemampuan perusahaan memenuhi kewajiban jangka pendeknya. Jika perusahaan dalam operasionalnya memperoleh laba yang optimal maka akan semakin lancar pendanaan dan pembiayaan perusahaan, dan sebaliknya. CR yang rendah menunjukkan risiko likuiditas yang tinggi, sedangkan CR yang tinggi menunjukkan adanya kelebihan aktiva lancar, yang akan memiliki pengaruh kurang baik terhadap profitabilitas perusahaan. Aktiva lancar secara umum menghasilkan return yang lebih rendah dibandingkan dengan aktiva tetap. Penelitian yang dilakukan Ulupui (2007) dan Prince et al. (2014) membuktikan bahwa CR berpengaruh positif signifikan terhadap return saham.

Leverage merupakan penggunaan aktiva dan sumber dana oleh perusahaan yang memiliki biaya tetap yang berasal dari pinjaman karena memiliki bunga sebagai beban tetap dengan maksud untuk meningkatkan keuntungan potensial pemegang saham (Sjahrial, 2007). Leverage adalah kemampuan perusahaan untuk memenuhi kewajiban finansialnya baik dalam jangka waktu yang pendek atau panjang, atau mengukur sejauh mana suatu aktiva perusahaan dibiayai oleh hutang (Wiagustini, 2010:76). Menurut penelitian Wibawa (2015) semakin tinggi leverage, maka para investor akan memperoleh kesejahteraan bukan dalam bentuk 
deviden tunai, melainkan dalam bentuk yang lain seperti saham bonus atau deviden saham. Leverage adalah rasio yang menggambarkan hubungan antara hutang perusahaan terhadap modal maupun aktiva. Leverage merupakan pengukur besarnya aktiva yang dibiayai dengan hutang. Kemampuan hutang yang digunakan untuk membiayai aktiva berasal dari kreditor, bukan dari pemegang saham perusahaan maupun investor yang menanamkan modalnya (Sudarmadji dan Sularto, 2007). Leverage dalam penelitian ini dapat diproksikan dengan debt to equity rasio (DER). DER adalah rasio yang digunakan untuk menilai hutang dengan seluruh ekuitas serta mampu memberikan petunjuk umum tentang kelayakan dan risiko keuangan perusahaan. Investor biasanya menghindari saham yang memiliki DER yang tinggi karena itu mencerminkan risiko perusahaan yang relatif tinggi (Kasmir, 2012:158).

Penelitian dari Farooq (2016) menunjukkan bahwa Leverage keuangan berpengaruh positif terhadap nilai perusahaan. Crabb (2003) mengatakan bahwa perusahaan yang pembayaran dividennya rendah mempengaruhi harga saham secara positif pada pengumuman penawaran hutang. Leverage menyatakan kebijakan hutang, sehingga hutang dapat digunakan untuk memperkirakan keuntungan yang kemungkinan dapat diperoleh bagi investor jika berinvestasi pada suatu perusahaan. Sedangkan Penelitian Panayiotis dan Georgia (2013) menyatakan bahwa faktor risiko leverage mempunyai hubungan negatif dengan return saham pada leverage rendah dan sebaliknya pada leverage menengah dan tinggi berhubungan positif di empat negara Eropa Selatan yang diteliti. Penelitian dari Stella (2009) dan Nathanael (2008) juga menyimpulkan bahwa DER 
berpengaruh negatif terhadap return saham karena DER yang tinggi mencerminkan risiko perusahaan yang relatif tinggi.

Ukuran perusahaan merupakan gambaran dari perusahaan yang mempunyai kemampuan finansial dalam satu periode tertentu (Joni dan Lina, 2010). Besarnya sebuah perusahan dapat dilihat dengan banyaknya aktivitas yang dilakukan oleh perusahaan (Wimelda dan Marlinah, 2013). Mitton (2002) mengatakan bahwa banyak yang percaya jika ukuran perusahaan besar maka akan mengarah pada tata kelola perusahaan yang kuat dan akan menghasilkan kinerja perusahaan yang lebih baik. Ukuran perusahaan akan memainkan faktor penting dalam penelitian karena dapat mempengaruhi kinerja perusahaan. Drew dkk. (2003) menemukan perusahaan kecil tersebut lebih beresiko daripada perusahaan besar. Fama dan French (1992) juga menyimpulkan bahwa ukuran perusahaan berperan dalam menjelaskan variasi kinerja perusahaan. Karayaka dkk. (2017) menemukan adanya hubungan positif antara ukuran perusahaan, dengan nilai perusahaan. $\mathrm{Gu}$ (2003) telah menemukan bahwa ukuran perusahaan memiliki dampak positif pada tingkat pengembalian di pasar saham China. Talebnia et al. (2010) dan Fachrudin (2011) menemukan hasil penelitian yaitu bahwa ukuran perusahaan tidak berpengaruh terhadap kinerja perusahaan yang ditunjukkan oleh kemampuan perusahaan untuk memperoleh laba. Sementara Issham (2014) menyimpulkan bahwa ukuran perusahaan itu berpengaruh negatif terhadap kinerja perusahaan. Ukuran perusahaan diukur dari total asset (TA) yang dimiliki oleh perusahaan, yang dapat dipergunakan untuk kegiatan operasi perusahaan. 
Persaingan perusahaan barang konsumsi makanan dan minuman semakin lama menjadi semakin ketat sejak disahkannya organisasi perdagangan dunia. Dengan terbentuknya World Trade Organization (WTO) di tahun 1994 pasar dunia cenderung semakin terbuka dan bebas hambatan (Riyadi, 2012). Untuk itu perusahaan industri barang konsumsi makanan dan minuman di Indonesia memerlukan dana tambahan untuk menjaga kelangsungan hidup perusahaan, serta mampu bersaing dengan produk luar negeri.

Industri makanan dan minuman tumbuh lebih cepat pada tahun 2016. Kementerian Perindustrian mencatat pada kuartal III pertumbuhan industri ini mencapai 9,82 persen. Pada periode yang sama tahun lalu, pertumbuhan industri ini hanya 6,9 persen. Industri makanan dan minuman menjadi penyumbang terbesar sektor nonmigas terhadap Produk Domestik Bruto (PDB). Porsinya dalam PDB kuartal III mencapai 33,6 persen, dengan nilai Rp 192,69 triliun. Pertumbuhan ini juga dipengaruhi besarnya surplus perdagangan luar negeri produk makanan dan minuman. Nilai ekspor produk makanan dan minuman termasuk minyak kelapa sawit pada Januari-September 2016 mencapai US\$ 17,86 miliar. Sedangkan impornya hanya US\$ 6,81 miliar. Dari sisi investasi, sampai dengan triwulan III tahun ini pun cukup besar. Total nilai investasi asing (penanaman modal asing/PMA) tercatat mencapai US\$ 1,6 miliar dan penanaman modal dalam negeri (PMDN) sebesar Rp24 triliun untuk PMDN.

Penelitian ini menggunakan perusahaan food and beverage sebagai penelitian karena saham yang berasal dari produk makanan dan minuman merupakan saham yang banyak diminati oleh investor. Saham pada perusahaan 
food and beverage tidak terpengaruh oleh pergerakan situasi ekonomi makro atau kondisi bisnis secara umum, perusahaan tersebut mampu memberikan bagian keuntungan yang diberikan emiten kepada pemegang sahamnya. Perusahaan Food and beverage yang terdaftar di Bursa Efek Indonesia merupakan salah satu sektor yang bertahan saat terjadi krisis di Indonesia karena sebagian produk makanan dan minuman merupakan kebutuhan pokok dari masyarakat. Industri makanan dan minuman di Indonesia yang terdaftar di Bursa Efek Indonesia (BEI) memiliki harapan yang positif dalam perkembangannya didukung juga oleh pertumbuhan masyarakat yang semakin meningkat. Mengacu pada penelitian yang dilakukan pada perusahaan food and beverage pada BEI mengenai pengaruh profitabilitas, likuiditas, leverage, ukuran perusahaan terhadap return saham yang masih kontradiktif (research gap) maka diperlukan penelitian lebih lanjut dengan tujuan untuk memperjelas temuan penelitian selanjutnya.

Menurut Legiman (2015) return saham merupakan hasil yang diperoleh dari investasi. Harapan dalam memperoleh return juga terjadi pada asset financial. Dalam suatu manajemen investasi, return atau tingkat keuntungan adalah suatu imbalan yang didapatkan dari investasi. Solechan (2009) berpendapat bahwa setiap investasi, baik jangka pendek maupun jangka panjang mempunyai tujuan utama yaitu memperoleh keuntungan yang disebut return, baik secara langsung maupun tidak langsung. Return saham dapat berupa return realisasi yang sudah terjadi atau return ekspektasi yang belum terjadi, akan tetapi diharapkan akan terjadi di masa yang akan datang. Return realisasi dihitung berdasarkan data historis. Return realisasi dapat digunakan sebagai salah satu pengukuran kinerja 
perusahaan dan dapat juga digunakan sebagai dasar penentu return ekspektasi dan risiko di masa yang akan datang.

Berbagai upaya akan dilakukan investor untuk memperoleh keyakinan bahwa investasi yang akan dilaksanakannya mendapatkan pengembalian (return) yang sesuai dengan yang diharapkan. Salah satunya berasal dari informasi laporan keuangan yang diterbitkan suatu perusahaan yang akan menjadi target investasinya. Dalam melakukan investasi investor diposisikan pada ketidakpastian (uncertainly) antara return yang diperoleh dengan risiko yang akan dihadapi. Semakin besar return yang diharapkan akan diperoleh dari investasi, maka semakin besar juga risikonya, dan dapat dikatakan bahwa return ekspektasi memiliki hubungan positif dengan risiko. Risiko yang lebih tinggi biasanya dikorelasikan dengan peluang agar mendapatkan return yang lebih tinggi juga (high risk high return, low risk low return).

Menurut Irfan Fahmi (2012:80) rasio profitabilitas yaitu untuk mengukur efektivitas manajemen secara keseluruhan yang ditujukan oleh besar kecilnya tingkat keuntungan yang diperoleh dalam hubungannya dengan penjualan maupun investasi. Semakin baik rasio profitabilitas maka semakin baik menggambarkan kemampuan tingginya perolehan keuntungan perusahaan. Menurut Kasmir (2014:196) rasio profitabilitas merupakan rasio untuk menilai kemampuan perusahaan dalam mencari keuntungan. Profitabilitas menunjukkan kemampuan perusahaan memperoleh laba atau ukuran efektivitas pengelolaan manajemen perusahaan. Kemampuan memperoleh laba bisa diukur dari modal sendiri maupun dari seluruh dana yang diinvestasikan ke dalam perusahaan. Dari batasan ini kita 
akan mengatur rentabilitas perusahaan jika kita mengetahui berapa besar kita menggunakan modal sendiri untuk memperoleh laba tersebut (Wiagustini, 2010:77).

Likuiditas menunjukkan kemampuan perusahaan untuk membayar utang lancar (jangka pendek) dengan menggunakan aktiva lancar yang dimiliki. Jika posisi dana lancar perusahaan yang tersedia lebih besar daripada utang lancar maka perusahaan selalu likuid. Perusahaan yang tidak likuid dapat diartikan sebagai perusahaan yang tidak sehat. Oleh karena itu, perusahaan perlu mengatur, menjaga dan memelihara likuiditas yang baik untuk menjaga kredibilitas kepada kreditur (Wiagustini, 2014:85). Dengan kata lain likuiditas berguna untuk mengetahui seberapa besar perusahaan dapat membiayai dan memenuhi kewajiban atau utang pada saat jatuh tempo (Kasmir, 2011:145).

Likuiditas memiliki beberapa rasio yang dimana rasio-rasio tersebut memiliki fungsi untuk mengukur kemampuan perusahaan memenuhi kewajiban keuangan jangka pendek (Kasmir, 2011:133), cash ratio merupakan ukuran likuiditas yang paling ketat karena hanya mempertimbangan kas dan surat berharga jangka pendek sebagai komponen untuk memenuhi kewajiban yang jatuh tempo. Apabila utang perusahaan ditagih, perusahaan akan mampu untuk memenuhi utang tersebut, terutama utang yang sudah jatuh tempo. Rasio likuiditas yang baik membuat suatu jaminan bagi investor untuk melakukan investasi di perusahaan tersebut sehingga akan mempengaruhi struktur modal perusahaan (Muhajir dan Triyono, 2010). 
Leverage digunakan untuk menggambarkan kemampuan perusahaan untuk menggunakan aktiva atau dana yang mempunyai beban tetap (fixed cost assets or funds) untuk memperbesar tingkat penghasilan (return) bagi pemilik perusahaan. Sutrisno (2006) mendefinisikan leverage sebagai penggunaan aktiva tetap atau sumber dana dimana atas penggunaan dana tersebut, perusahaan harus menanggung biaya tetap atau membayar beban tetap. Semakin besar tingkat leverage berarti tingkat ketidakpastian (uncertainty) dari penghasilan yang akan diperoleh akan semakin tinggi pula, tetapi pada saat yang sama hal tersebut juga akan memperbesar jumlah penghasilan yang akan diperoleh. Tingkat leverage ini berbeda-beda antara perusahaan yang satu dengan perusahaan lainnya, atau dari satu periode ke periode lainnya di dalam suatu perusahaan, tetapi yang jelas, semakin tinggi tingkat leverage akan semakin tinggi resiko yang dihadapi serta semakin besar tingkat penghasilan (return) yang diharapkan. Istilah resiko (risk) dalam leverage dimaksudkan dengan ketidakpastian (uncertainty) dalam hubungannya dengan kemampuan perusahaan membayar kewajiban-kewajiban tetapnya (fixed payment obligation).

Diharapkan setelah perusahaan menerapkan leverage ini, tingkat kekayaan perusahaan juga ikut meningkat. Permasalahan leverage akan selalu dihadapi oleh perusahaan karena leverage selalu berurusan dengan biaya tetap operasi maupun biaya finansial. Biaya tetap operasi adalah biaya yang harus dikeluarkan oleh perusahaan karena mengadakan kegiatan investasi baik itu investasi perlengkapan, peralatan, ataupun juga investasi jangka panjang. Biaya finansial adalah biaya yang wajib diperhitungkan oleh perusahaan akibat dari fungsi 
perusahaan dalam menjalankan pendanaan untuk kelangsungan perusahaan itu sendiri. Beban ataupun biaya tetap yang telah perusahaan hitung merupakan dampak yang harus menjadi tanggung jawab perusahaan karena telah melakukan fungsi finansial dan juga keputusan dalam mengatur laju keuangan perusahaan.

Ukuran perusahaan dapat diinterpretasikan sebagai skala operasi perusahaan (besar atau kecil). Skala operasi ini menimbulkan berbagai penafsiran, antara lain luasnya pangsa pasar, kuatnya permodalan, serta tingginya tingkat penjualan. Salah satu cara yang dapat digunakan untuk menilai besar kecilnya suatu perusahaan ialah dengan melihat total aktiva perusahaan tersebut. Perusahaan yang dengan total aktiva yang besar biasanya telah mapan dalam permodalan dan memiliki kemampuan dalam mengelola sumber-sumber keuangannya karena perusahaan tersebut biasanya bukan merupakan perusahaan baru sehingga cukup berpengalaman dalam industri (Delfina, 2012).

Variabel ukuran perusahaan dapat diukur melalui ukuran aktiva, penjualan bersih, dan kapitalisasi pasar. Dalam memenuhi kebutuhan informasi bagi para krediturnya, perusahaan yang tumbuh besar memiliki kewajiban lebih besar dari pada yang lain. Hal ini dapar dilihat melalui laporan tahunan yang lebih terinci (Subiyantoro, 1997). Ukuran perusahaan menggambarkan besar kecilnya suatu perusahaan. Ukuran perusahaan yang menunjukkan besar kecilnya perusahaan dapat dilihat dari besar kecilnya modal yang digunakan, total aktiva yang dimiliki, atau total penjualan yang diperoleh.

Ukuran perusahaan dinyatakan dengan total aset, jika semakin besar total aset perusahaan maka akan semakin besar pula ukuran perusahaan tersebut. 
Perusahaan yang memiliki total aset besar menunjukkan bahwa perusahaan tersebut relatif lebih stabil dan mampu menghasilkan laba yang lebih besar dibandingkan perusahaan yang memiliki total aset sedikit atau rendah. Perusahaan yang relatif besar kinerjanya akan dilihat oleh publik sehingga perusahaan tersebut akan melaporkan kondisi keuangannya dengan lebih berhati-hati, lebih menunjukkan kejelasan informasi yang terkandung di dalamnya dan lebih transparan. Oleh karena itu, semakin besar ukuran suatu perusahaan memiliki kualitas laba yang lebih tinggi.

Profitabilitas digunakan untuk mengetahui seberapa jauh perusahaan mampu untuk menghasilkan laba atau ukuran efektivitas pengelolaan manajemen perusahaan. Kemampuan memperoleh laba dapat diukur dari modal sendiri maupun seluruh dana yang diinvestasikan ke dalam perusahaan (Wiagustini, 2010:79). Profitabilitas pada penelitian ini diproksikan dengan ROA. Semakin tinggi ROA maka dapat diartikan suatu perusahaan semakin efektif dalam memanfaatkan aktivanya untuk menghasilkan laba bersih setelah pajak, dengan meningkatnya ROA maka profitabilitas perusahaan semakin baik sehingga mendapatkan return yang besar. Pernyataan tersebut didukung oleh hasil penelitian yang dilakukan oleh Daljono (2013), Kabajeh et al. (2012), Haghiri (2012) serta Har \& Ghafar (2015) bahwa ROA memiliki hubungan yang positif terhadap return saham. Berdasarkan uraian diatas maka dapat dirumuskan hipotesis sebagai berikut :

$\mathrm{H}_{1}$ : Profitabilitas berpengaruh positif signifikan terhadap return saham 
Likuiditas mengukur kemampuan jangka pendek perusahaan dengan melihat aktiva lancar perusahaan terhadap hutang lancar. Current Ratio menunjukkan sejauh mana aktiva lancar menutup kewajiban-kewajiban lancar. CR yang terlalu tinggi dianggap tidak bagus dikarenakan menunjukkan banyaknya dana yang menganggur dan pada akhirnya bisa mengurangi laba perusahaan, begitu pula jika CR yang rendah biasanya dianggap menunjukkan adanya masalah dalam likuiditas (Sawir, 2009:10). Semakin baiknya CR mencerminkan semakin likuid perusahaan tersebut, sehingga perusahaan mempunyai kemampuan untuk memenuhi kemampuan jangka pendeknya dengan baik dan ini akan meningkatkan kredibilitas dari perusahaan tersebut di mata investor sehingga mampu meningkatkan return sahamnya. Hal ini terbukti dari penelitian yang dilakukan oleh Ulupui (2007) dan Shandy (2013) yang dimana CR berpengaruh positif terhadap return saham. Berdasarkan uraian diatas maka dapat dirumuskan hipotesis sebagai berikut :

$\mathrm{H}_{2}$ : Likuiditas berpengaruh positif signifikan terhadap return saham

Leverage merupakan hubungan antara hutang perusahaan terhadap modal maupun aktiva. Debt to Equity Ratio (DER) merupakan rasio yang membandingkan total hutang dengan total modal sendiri. Semakin besar DER, maka semakin besar pula beban perusahaan terhadap pihak luar, baik berupa pokok atau berupa bunga pinjaman. Jika beban perusahaan semakin berat maka kinerja perusahaan akan semakin memburuk dan berdampak pada return saham yang diperoleh. Hal ini sesuai dengan penelitian Soejoto (2001), Gilang (2012) dan Barakat (2014) memberikan bukti bahwa leverage berpengaruh negatif 
terhadap return saham. Berdasarkan uraian diatas maka dapat dirumuskan hipotesis sebagai berikut :

$\mathrm{H}_{3}$ : Leverage berpengaruh negatif signifikan terhadap return saham.

Ukuran perusahaan adalah suatu skala dimana besar atau kecilnya perusahaan dapat diklasifikasikan menurut berbagai cara, antara lain melalui total aktiva, long size, nilai pasar saham dan lain-lain. Ukuran perusahaan menunjukkan semakin besar dan mapan suatu perusahaan akan mempunyai peluang yang lebih besar ke pasar modal, begitupun sebaliknya. Semakin efisien pasar, maka informasi mengenai peningkatan ukuran perusahaan akan semakin meyakinkan dapat meningkatkan return saham. Teori tersebut didukung oleh hasil penelitian Sugiarto (2011), Yuliantari dan Sujana (2014), Prince et al. (2014) yang menyatakan ukuran perusahaan berpengaruh positif terhadap return saham. Berdasarkan uraian diatas maka dapat dirumuskan hipotesis sebagai berikut :

$\mathrm{H}_{4}$ : Ukuran perusahaan berpengaruh positif terhadap return saham.

\section{METODE PENELITIAN}

Penelitian ini dilakukan pada perusahaan Food and beverage yang terdaftar pada Bursa Efek Indonesia (BEI) periode 2013 - 2016 dengan mengakses situs resmi BEI (www.idx.co.id)._Objek penelitian ini adalah return saham pada perusahaanfood and beverageyang dipengaruhi oleh profitabilitas, likuiditas, leverage, ukuran perusahaan yang terdaftar di Bursa Efek Indonesia (BEI) periode 2013-2016.

Populasi dalam penelitian ini adalah perusahaan yang dikategorikan ke dalam sektor food and beverage tahun 2013-2016 di Bursa Efek Indonesia (BEI). 
Teknik pengambilan sampel dalam penelitian ini adalah purposive sampling. Purposive sampling merupakan teknik pengambilan sampel dengan menggunakan kriteria tertentu. Kriteria yang dimaksud adalah

Tabel 1.

Proses Seleksi Sampel

\begin{tabular}{llc}
\hline No. & \multicolumn{1}{c}{ Kriteria Sampel } & Jumlah \\
\hline 1. & $\begin{array}{l}\text { Perusahaan go-public yang terdaftar di BEI pada subsektor food } \\
\text { and beverage pada tahun 2013-2016 }\end{array}$ & 16 \\
2. & $\begin{array}{l}\text { Perusahaan tidak menerbitkan laporan tahunan secara terus- } \\
\text { menerus pada periode tahun 2013-2016 }\end{array}$ & $(2)$ \\
& $\begin{array}{l}\text { Sampel yang digunakan } \\
\text { Jumlah data pengamatan }\end{array}$ & 14 \\
& Jumlah sampel akhir & 4 tahun \\
\end{tabular}

Sumber: Data diolah, 2018

Tabel 1 diatas menunjukkan bahwa perusahaan sektor food and beverage yang terdaftar di Bursa Efek Indonesia (BEI) adalah sebanyak 16 perusahaan. Perusahaan sektor food and beverage yang tidak menerbitkan laporan tahunan secara terus-menerus pada periode tahun 2013-2016 adalah sebanyak 14 perusahaan. Berdasarkan data tersebut, maka didapatkan jumlah sampel penelitian sebanyak 14 perusahaan dengan jumlah amatan selama 4 tahun pada periode 2013 sampai 2016, sehingga jumlah sampel pengamatan akhir adalah sebanyak 56.

Metode pengumpulan data yang digunakan dalam penelitian ini adalah metode observasi non partisipan, yaitu metode pengumpulan data dengan observasi atau pengamatan dimana peneliti tidak terlibat secara langsung dan hanya sebagai pengamat independen (Sugiyono, 2010:204). Metode pengumpulan data pada penelitian ini dilakukan dengan cara mengamati, mencatat, dan mempelajari dokumen-dokumen yang terdapat dalam situs www.idx.co.id. 
Analisis dalam penelitian ini diolah menggunakan program SPSS. Teknik analisis linear berganda digunakan untuk menggambarkan satu variabel terikat (dependen) dihubungkan dengan dua atau lebih variabel bebas (independen) yaitu:

$Y=\boldsymbol{u}+\beta_{1} X_{1}+\beta_{2 .} X_{2}+\beta_{3} X_{3}+\beta_{4} X_{4}+\varepsilon$

Keterangan :

$$
\begin{aligned}
& \mathrm{Y}=\text { Return Saham } \\
& u=\text { Nilai konstan } \\
& \beta=\text { Koefisien regresi variabel independen } \\
& \mathrm{X}_{1}=\text { Profitabilitas } \\
& \mathrm{X}_{2}=\text { Likuiditas } \\
& \mathrm{X}_{3}=\text { Leverage } \\
& \mathrm{X}_{4}=\text { Ukuran Perusahaan } \\
& \varepsilon=\text { Standar eror }
\end{aligned}
$$

\section{HASIL PENELITIAN DAN PEMBAHASAN}

Output statistik deskriptif diolah dengan menggunakan Statistical Product and Service Solutions (SPSS) 18.0. Adapun hasil statistik deskriptif setiap variabel dapat dilihat pada tabel 2

Tabel 2.

Hasil Statistik Deskriptif Variabel Penelitian

\begin{tabular}{lrrrrr}
\hline & N & Minimum & Maximum & \multicolumn{1}{c}{ Mean } & Std. Deviation \\
\hline Return Saham & 56 & -85 & 238 & 18.25 & 47.711 \\
Profitabilitas & 56 & -2.06 & 65.72 & 10.3495 & 10.75314 \\
Likuiditas & 56 & 51.39 & 712.54 & 211.1377 & 130.63737 \\
Leverage & 56 & .19 & 3.56 & 1.0920 & .58478 \\
Ukuran Perusahaan & 56 & 12.6181 & 18.5828 & 14.894892 & 1.5818191 \\
Valid N (listwise) & 56 & & & & \\
\hline
\end{tabular}

Sumber: Data diolah, 2018

Berdasarkan tabel statistik deskriptif diatas, terdapat berbagai informasi deskripsi dari variabel yang digunakan. Output tampilan Statistical Product and 
Service Solutions (SPSS) menunjukkan jumlah data pengamatan yang digunakan sebanyak 56 (n). Hasil uji statistik deskriptif pada Tabel 2 diatas, juga menunjukkan informasi bahwa return saham paling rendah (minimum) adalah sebesar -85 dimiliki oleh Nippon Indosari Corpindo Tbk pada tahun 2013 dan Return sahamyang paling tinggi (maksimum) adalah sebesar 238 yang dimiliki oleh Ultrajaya Milk Industry \& Trading Co. Tbk pada tahun 2013. Return saham memiliki nilai rata-rata sebesar 18,25 dengan nilai standar deviasi sebesar 47,711. Ini berarti bahwa terjadi perbedaan nilai Return saham yang diteliti terhadap nilai rata-ratanya sebesar 18,25 yang artinya bahwa nilai mean lebih besar dari pada standar deviasi, sehingga mengindikasikan bahwa hasil yang cukup baik.

Profitabilitas paling rendah (minimum) adalah sebesar -2,06 dimiliki oleh Tri Banyan Tirta Tbk pada tahun 2015 dan Profitabilitas yang paling tinggi (maksimum) adalah sebesar 65,72 yang dimiliki oleh Multi Bintang Indonesia Tbk pada tahun 2013. Profitabilitas memiliki nilai rata-rata sebesar 10,349 dengan nilai standar deviasi sebesar 8,753 . Ini berarti bahwa terjadi perbedaan nilai Profitabilitas yang diteliti terhadap nilai rata-ratanya sebesar 8,753, yang artinya bahwa nilai mean lebih besar dari pada standar deviasi, sehingga mengindikasikan bahwa hasil yang cukup baik.

Likuiditas paling rendah (minimum) adalah sebesar 51,39 dimiliki oleh Multi Bintang Indonesia Tbk pada tahun 2014 dan Likuiditas yang paling tinggi (maksimum) adalah sebesar 712,54 yang dimiliki oleh Delta Djakarta Tbk pada tahun 2016. Likuiditas memiliki nilai rata-rata sebesar 211,137 dengan nilai standar deviasi sebesar 130,637. Ini berarti bahwa terjadi perbedaan nilai 
Likuiditas yang diteliti terhadap nilai rata-ratanya sebesar 130,637, yang artinya bahwa nilai mean lebih besar dari pada standar deviasi, sehingga mengindikasikan bahwa hasil yang cukup baik.

Leverage paling rendah (minimum) adalah sebesar 0,19 dimiliki oleh Ultrajaya Milk Industry \& Trading Co. Tbk pada tahun 2016 dan Leverage yang paling tinggi (maksimum) adalah sebesar 3,56 yang dimiliki oleh Multi Bintang Indonesia Tbk pada tahun 2016. Leverage memiliki nilai rata-rata sebesar 1,092 dengan nilai standar deviasi sebesar 0,5847. Ini berarti bahwa terjadi perbedaan nilai Leverage yang diteliti terhadap nilai rata-ratanya sebesar 0,5847 , yang artinya bahwa nilai mean lebih besar dari pada standar deviasi, sehingga mengindikasikan bahwa hasil yang cukup baik.

Ukuran perusahaan paling rendah (minimum) adalah sebesar 12,6181 dimiliki oleh Sekar Laut Tbk pada tahun 2013 dan Ukuran perusahaan yang paling tinggi (maksimum) adalah sebesar 18,5828 yang dimiliki oleh Tri Banyan Tirta Tbk pada tahun 2016. Ukuran perusahaan memiliki nilai rata-rata sebesar 14,8948 dengan nilai standar deviasi sebesar 1,5818. Ini berarti bahwa terjadi perbedaan nilai Ukuran perusahaan yang diteliti terhadap nilai rata-ratanya sebesar 1,5818, yang artinya bahwa nilai mean lebih besar dari pada standar deviasi, sehingga mengindikasikan bahwa hasil yang cukup baik.

Analisis regresi linier berganda ini digunakan untuk menganalisis pengaruh Profitabilitas $\left(\mathrm{X}_{1}\right)$, Likuiditas $\left(\mathrm{X}_{2}\right)$, Leverage $\left(\mathrm{X}_{3}\right)$, dan Ukuran perusahaan $\left(\mathrm{X}_{4}\right)$ pada Return saham (Y). Analisis regresi linear berganda diolah dengan bantuan 
software SPSS 22 for Windows dengan hasil yang dapat dilihat pada Tabel 3 berikut.

\section{Tabel 3.}

Rangkuman Hasil Analisis Regresi Linear Berganda

\begin{tabular}{lcrrrr}
\hline \multicolumn{1}{c}{ Variabel } & \multicolumn{2}{c}{$\begin{array}{c}\text { Unstandardized } \\
\text { Coefficients } \\
\text { Std. error }\end{array}$} & $\begin{array}{c}\text { Standardized } \\
\text { Coefficients } \\
\text { Beta }\end{array}$ & t & Sig. \\
\hline (constant) & .148 & .126 & & 1.175 & .246 \\
Profitabilitas & .284 & .122 & .256 & 2.323 & .024 \\
Likuiditas & .366 & .134 & .301 & 2.729 & .009 \\
Leverage & -.191 & .093 & -.217 & -2.056 & .045 \\
Ukuran perusahaan & .372 & .134 & .326 & 2.782 & .008 \\
\hline
\end{tabular}

Sumber: Data diolah, 2018

Dari hasil analisis regresi linear berganda pada Tabel 3 tersebut, maka dapat dibuat persamaan sebagai berikut.

$$
Y=0,148+0,284 X_{1}+0,366 X_{2}-0,191 X_{3}+0,372 X_{4}
$$

Berdasarkan persamaan di atas, dapat dijelaskan bahwa nilai konstanta sebesar 0,148, yakni apabila nilai Profitabilitas $\left(\mathrm{X}_{1}\right)$, Likuiditas $\left(\mathrm{X}_{2}\right)$, Leverage $\left(\mathrm{X}_{3}\right)$, dan Ukuran perusahaan $\left(\mathrm{X}_{4}\right)$,sama dengan nol, maka Return saham (Y) tidak meningkat atau sama dengan 0,148 .

$\beta_{1}=0,284$, jika nilai Profitabilitas $\left(X_{1}\right)$ bertambah 1 satuan, maka nilai dari Return saham (Y) akan bertambah sebesar 0,284 dengan asumsi variabel bebas lainnya konstan.

$\beta_{2}=0,366$, jika nilai Likuiditas $\left(\mathrm{X}_{2}\right)$ bertambah 1 satuan, maka nilai dari Return saham (Y) akan bertambah sebesar 0,366 dengan asumsi variabel bebas lainnya konstan.

$\beta_{3}=-0,191$ jika nilai Leverage $\left(X_{3}\right)$ bertambah 1 satuan, maka nilai dari Return saham (Y) akan berkurang sebesar 0,191 dengan asumsi variabel bebas lainnya konstan. 
$\beta_{4}=0,372$, jika nilai Ukuran perusahaan $\left(X_{4}\right)$ bertambah 1 satuan, maka nilai dari Return saham (Y) akan bertambah sebesar 0,372 dengan asumsi variabel bebas lainnya konstan.

Hasil analisis regresi menunjukkan bahwa profitabilitas secara statistik berpengaruh positif dan signifikan pada return saham Perusahaan sektor food and beverage yang terdaftar di BEI periode 2013 - $2016\left(\mathrm{H}_{1}\right.$ diterima). Secara teori Profitabilitas digunakan untuk mengetahui seberapa jauh perusahaan mampu untuk menghasilkan laba atau ukuran efektivitas pengelolaan manajemen perusahaan. Kemampuan memperoleh laba dapat diukur dari modal sendiri maupun seluruh dana yang diinvestasikan ke dalam perusahaan (Wiagustini, 2010:79). Meningkatnya profitabilitas akan menyebabkan bertambahnya return saham yang diperoleh perusahaan. Semakin tinggi ROA maka dapat diartikan suatu perusahaan semakin efektif dalam memanfaatkan aktivanya untuk menghasilkan laba bersih setelah pajak, dengan meningkatnya ROA maka profitabilitas perusahaan semakin baik sehingga mendapatkan return yang besar. Hasil penelitian ini sesuai dengan hasil penelitian yang dilakukan oleh Daljono (2013), Kabajeh et al. (2012), Haghiri (2012) serta Har \& Ghafar (2015) yang menyatakan bahwa ROA memiliki hubungan yang positif terhadap return saham.

Hasil analisis regresi menunjukkan bahwa Likuiditas secara statistik berpengaruh positif dan signifikan terhadap return saham perusahaan sektor food and beverage yang terdaftar di BEI periode 2013 - $2016\left(\mathrm{H}_{2}\right.$ diterima $)$. Likuiditas mengukur kemampuan jangka pendek perusahaan dengan melihat aktiva lancar perusahaan terhadap hutang lancar. Current Ratio menunjukkan sejauh mana 
aktiva lancar menutup kewajiban-kewajiban lancar. CR yang terlalu tinggi dianggap tidak bagus dikarenakan menunjukkan banyaknya dana yang menganggur dan pada akhirnya bisa mengurangi laba perusahaan, begitu pula jika CR yang rendah biasanya dianggap menunjukkan adanya masalah dalam likuiditas (Sawir, 2009:10). Semakin meningkatnya likuiditas maka akan dapat meningkatkan return saham yang diperoleh perusahaan. Semakin baiknya CR mencerminkan semakin likuid perusahaan tersebut, sehingga perusahaan mempunyai kemampuan untuk memenuhi kemampuan jangka pendeknya dengan baik dan ini akan meningkatkan kredibilitas dari perusahaan tersebut di mata investor sehingga mampu meningkatkan return sahamnya. Hasil penelitian inididukung dengan temuan penelitian yang dilakukan oleh Ulupui (2007) dan Shandy (2013) yang memperoleh hasil bahwa CR berpengaruh positif terhadap return saham, yaitu semakin tinggi tingkat likuiditas pada perusahaan, maka semakin tinggi tingkat return saham.

Hasil analisis regresi menunjukkan bahwa Leverage secara statistik berpengaruh negatif dan signifikan pada Return saham Perusahaan sektor food and beverage yang terdaftar di BEI periode 2013 - $2016\left(\mathrm{H}_{3}\right.$ diterima). Leverage merupakan hubungan antara hutang perusahaan terhadap modal maupun aktiva. Debt to Equity Ratio (DER) merupakan rasio yang membandingkan total hutang dengan total modal sendiri. Apabila leverage dapat dikelola dengan baik, maka dapat meningkatkan return saham perusahaan. Semakin rendah DER, maka semakin rendah pula beban perusahaan terhadap pihak luar, baik berupa pokok atau berupa bunga pinjaman. Jika beban perusahaan semakin ringan maka kinerja 
perusahaan akan semakin meningkat dan berdampak pada return saham yang diperoleh. Begitu pula sebaliknya semakin besar DER, maka semakin besar pula beban perusahaan terhadap pihak luar, baik berupa pokok atau berupa bunga pinjaman. Jika beban perusahaan semakin berat maka kinerja perusahaan akan semakin memburuk dan berdampak pada return saham yang diperoleh.Hasil penelitian di dukung oleh temuan Soejoto (2001), Gilang (2012) dan Barakat (2014) yang memberikan bukti bahwa leverage berpengaruh negatif terhadap return saham.

Hasil analisis regresi menunjukkan bahwa ukuran perusahaan secara statistik berpengaruh positif dan signifikan pada return saham Perusahaan sektor food and beverage yang terdaftar di BEI periode 2013 - $2016\left(\mathrm{H}_{4}\right.$ diterima $)$. Secara teori ukuran perusahaan adalah suatu skala dimana besar atau kecilnya perusahaan dapat diklasifikasikan menurut berbagai cara, antara lain melalui total aktiva, long size, nilai pasar saham dan lain-lain. Ukuran perusahaan menunjukkan semakin besar dan mapan suatu perusahaan akan mempunyai peluang yang lebih besar ke pasar modal, begitupun sebaliknya. Semakin efisien pasar, maka informasi mengenai peningkatan ukuran perusahaan akan semakin meyakinkan dapat meningkatkan return saham. Bila dilihat dari hubungannya, antara ukuran perusahaan dengan return saham memiliki hubungan positif (searah). Pernyataan tersebut menunjukkan bahwa semakin besarukuran perusahaan dapat mengakibatkan return saham perusahaan mengalami peningkatan pula. Hasil penelitian ini menunjukkan bahwa ukuran perusahaan mampu meningkatkan return saham. Hasil penelitian ini sesuai dengan hasil 
penelitian yang dilakukan oleh Devi Kusumayanti (2014), Andhika dan Sujana (2016) yang menyatakan bahwa jumlah Ukuran perusahaan berpengaruh positif terhadap return saham LPD. Hasil penelitian ini juga di dukung oleh hasil penelitian Sugiarto (2011), Yuliantari dan Sujana (2014), Prince et al. (2014) yang menyatakan ukuran perusahaan berpengaruh positif dengan return saham.

Uji koefisien determinasi $\left(\mathrm{R}^{2}\right)$ digunakan untuk mengetahui dan mengukur kemampuan model dalam menerangkan variasi variabel independen. Peneliti menggunakan nilai adjusted $\mathrm{R}^{2}$ pada saat mengevaluasi yang mana model regresi terbaik, karena tidak seperti $\mathrm{R}^{2}$, nilai adjusted $\mathrm{R}^{2}$ dapat naik atau turun apabila satu variabel independen ditambahkan ke dalam model. Hasil uji koefisien determinasi dalam penelitian ini disajikan dalam Tabel 4 sebagai berikut:

Tabel 4.

Hasil Uji Koefisien Determinasi

\begin{tabular}{rcccc}
\hline Model & R & R Square & Adjusted R Square & Std. Error of the Estimate \\
\hline 1 & $.685^{\text {a }}$ & .469 & .427 & .87753288 \\
\hline
\end{tabular}

Sumber: Data diolah, 2018

Hasil uji memberikan hasil dimana diperoleh besarnya adjusted $\mathrm{R}^{2}$ (koefisien determinasi yang telah disesuaikan) pada Tabel 8 adalah 0,427. Ini berarti variasi Return saham Perusahaan sektor food and beverage yang terdaftar di BEI periode 2013 - 2016 dapat dipengaruhi secara signifikan oleh variabel Profitabilitas $\left(\mathrm{X}_{1}\right)$, Likuiditas $\left(\mathrm{X}_{2}\right)$, Leverage $\left(\mathrm{X}_{3}\right)$, dan Ukuran perusahaan $\left(\mathrm{X}_{4}\right)$, sebesar 42,7 sedangkan sisanya sebesar 57,3 persen dijelaskan oleh faktor-faktor lain.

Implikasi dari hasil penelitian ini mencakup dua hal, yaitu implikasi teoritis dan praktis. Penelitian yang dilakukan diharapkan dapat memberikan kontribusi 
mengenai pengaruh profitabilitas, likuiditas, leverage dan ukuran perusahaan pada return saham. Hasil uji hipotesis dalam penelitian ini ditemukan bahwa leverage berpengaruh negatif pada return saham. Perusahaan yang memiliki hutang yang tinggi mengindikasikan bahwa beban perusahaan terhadap pihak luar, baik berupa pokok atau berupa bunga pinjaman semakin berat, maka hal tersebut akan memberikan dampak negatif pada respon para pelaku pasar, sehingga kinerja perusahaan akan semakin memburuk dan berdampak pada return saham yang diperoleh. Sedangkan hasil uji hipotesis mengenai profitabilitas, likuiditas, dan ukuran perusahaan menunjukkan pengaruh yang positif pada return saham, maka dengan adanya informasi terkait ROA, Current Ratio dan ukuran perusahaan tersebut, maka investor akan memberikan respon yang positif, sehingga terjadi perubahan volume perdagangan saham yang akan mempengaruhi return saham. Penelitian ini memberikan implikasi bagi investor sebagai pertimbangan dan pengetahuan mengenai return saham serta faktor-faktor yang mempengaruhinya. Investor dalam melakukan investasi atau penanaman modal di suatu perusahaan perbankan dapat melihat ROA, current ratio, DER dan ukuranyang dimiliki oleh perusahaan, karena hal tersebut dapat mempengaruhi return saham yang akan diperoleh investor.

\section{SIMPULAN DAN SARAN}

Berdasarkan hasil analisis penelitian dan hasil pembahasan pada bab sebelumnya maka simpulan dari penelitian ini adalah profitabilitas berpengaruh positif signifikan terhadap return saham perusahaan sektor food and beverage yang terdaftar di BEI periode 2013 - 2016. Hasil penelitian ini menunjukkan 
bahwa semakin tinggi ROA maka dapat diartikan suatu perusahaan semakin efektif dalam memanfaatkan aktivanya untuk menghasilkan laba bersih setelah pajak, dengan meningkatnya ROA maka profitabilitas perusahaan semakin baik sehingga mendapatkan return yang besar.

Likuiditas berpengaruh positif signifikan terhadap return saham perusahaan sektor food and beverage yang terdaftar di BEI periode 2013 - 2016. Hal ini mengindikasikan bahwa Semakin baiknya CR mencerminkan semakin likuid perusahaan tersebut, sehingga perusahaan mempunyai kemampuan untuk memenuhi kemampuan jangka pendeknya dengan baik dan ini akan meningkatkan kredibilitas dari perusahaan tersebut di mata investor sehingga mampu meningkatkan return sahamnya.

Leverage berpengaruh negatif signifikan terhadap return saham perusahaan sektor food and beverage yang terdaftar di BEI periode 2013 - 2016 . Hasil penelitian ini mengindikasikan bahwa Semakin besar DER, maka semakin besar pula beban perusahaan terhadap pihak luar, baik berupa pokok atau berupa bunga pinjaman. Jika beban perusahaan semakin berat maka kinerja perusahaan akan semakin memburuk dan berdampak pada return saham yang diperoleh.

Ukuran perusahaan berpengaruh positif signifikan terhadap return saham perusahaan sektor food and beverage yang terdaftar di BEI periode 2013 - 2016 . Hasil penelitian ini mengindikasikan bahwa semakin besar ukuran perusahaan menunjukkan semakin besar dan mapan suatu perusahaan tersebut sehingga mempunyai peluang yang lebih besar ke pasar modal, maka informasi mengenai 
peningkatan ukuran perusahaan akan semakin meyakinkan dan dapat meningkatkan return saham.

Berdasarkan hasil analisis penelitian, pembahasan dan kesimpulan terdapat beberapa saran yang dapat dipergunakan sebagai bahan pertimbangan dalam menentukan kebijakan terkait faktor-faktor yang mempengaruhi Return saham Perusahaan sektor food and beverage yang terdaftar di BEI periode 2013 - 2016 dimasa mendatang, antara lain perusahaan sebaiknya lebih meningkatkan usaha dalam pencapaian profitabilitas dan mengoptimalkan ukuran perusahaan yang diperoleh untuk bisa lebih meningkatkan return sahamnya sehingga nantinya mampu beroperasi secara konsisten dan terus menerus tanpa berpacu terhadap halhal yang mempengaruhi turunnya keberlangsungan dari operasi perusahaan tersebut. Penelitian selanjutnya dapat mempertimbangkan untuk menggunakan ukuran return saham lainnya atau objek penelitian selain Perusahaan sektor food and beverage yang terdaftar di BEI periode 2013 - 2016. Penelitian selanjutnya diharapkan dapat menambah jumlah sampel perusahaan yang akan dijadikan sampel penelitian. Periode waktu penelitian selanjutnya dapat diperpanjang misalnya lima tahun atau lebih, sehingga dapat dilakukan analisis yang lebih objektif.

\section{REFERENSI}

Arista, Desi dan Astohar, Analisis Faktor-Faktor yang Mempengaruhi Return Saham (Kasus pada Perusahaan Manufaktur yang Go Public di BEI Periode Tahun 2005-2009). Jurnal Ilmu Manajemen dan Akuntansi Terapan, vol. 3, No. 1, hal. 1-15.

Crabb, Peter R. (2003). Finance and Investment using The Wall Street Journal. New York: McGraw-Hill. 
Daljono, Bramantyo Nugroho. (2013). Pengaruh Kinerja Keuangan Terhadap Return Saham (Studi Empiris Perusahaan Automotive and Component yang Listing di Bursa Efek Indonesia Periode 2005-2011). Diponegoro Journal Of Accounting, 2(1), h: 1-11.

Delfina, Yuniati. (2012). Analisis Hubungan Struktur Kepemilikan dan Ukuran Perusahaan dengan Peringkat Obligasi (Studi Empiris pada Perusahaan Non Keuangan yang Terdaftar di BEI). Skripsi: Universitas Indonesia.

Drew, M.E, Naughton T, \& Veeraraghavan M. (2003). Firm size, book-to-market equity and security return: Evidence from the shanghai stock exchange. Austral. J. Manag. 28(2): 119-141.

Fahmi, Irham. (2012). Manajemen Investasi. Jakarta Selatan: Salemba Empat.

Fama, E., \& French, K. (2002). Testing trade-off and pecking order predictions about dividends and debt. The Review of Financial Studies, 15(1), 1-33.

Farooq, Muhammad Azhar and Ahsan Masood . (2016). Impact of Financial Leverage on Value of Firms: Evidence from Cement Sector of Pakistan Research Journal of Finance and Accounting, Vol.7, No.9, 2016

Gilang Pradika. (2012). The Influence of Financial Ratio Toward Stock Price, 2012- Empirical Study on Listed Companies in Indonesia Stock Exchange of LQ45 in 2009-2011. Journal Internasional Undergraduate Program In Accounting Faculty of Economic and Business Brawijaya University.

Haghiri, Amir and Soleyman Haghiri. (2012). The Investigation of Effective Factors on Stock Return Wish Emphasis on ROA and ROE Ratios in Tehran Stock Exchange (TSE). Journal of Basic and Applied Scientific Research, 2(9), pp: 9097-91103.

Har, Wong Pik and Ghafar, M.A.A. (2015). The Impact of Accounting Earnign on Stock Return: The Case of Malaysia's Plantation Industry. International Journal of Business And Management, 10(4), pp; 155-156.

Jones, P. Charles. (2006). Investments: Analysis and Management. Journal of Financial Economics, 2 (4), hal: 405-460.

Joni dan Lina. (2010). Faktor-Faktor yang Mempengaruhi Struktur Modal. Jurnal Bisnis dan Akuntansi. 12(2): hlm: 81-96.

Kabajeh, M.A.M., Said, M.A.A.N., and Firas, N.D. (2012). The Relationship Between The ROA, Roe, and ROI Ratios With Jordanian Insurance Public 
Companies Market Share Price. International Journal Of Humanities And Social Science, 2(11), pp: 115-120.

Kasmir. (2011). Analisis Laporan Keuangan. Jakarta: PT. Raja Grafindo Persada.

Kasmir. (2014). Analisis Laporan Keuangan. Jakarta: Raja Grafindo Persada.

Legiman, Fachreza Muhammad, et al. (2015). Faktor-faktor yang mempengaruhi return saham pada perusahaan agroindustry yang terdaftar di Bursa Efek Indonesia periode 2009-2012. Jurnal EMBA, vol.3 No.3.

Malintan, Rio. (2012). Pengaruh Current Ratio (CR), Debt To Equity Ratio (DER), Price Earning Ratio (PER), dan Return On Asset (ROA) Terhadap Return Saham Perusahaan Pertambangan yang Terdaftar di Bursa Efek Indonesia Tahun 2005-2010. Jurnal Akuntansi Fakultas Ekonomi dan Bisnis Brawijaya.

Mitton T. (2002). A cross-firm analysis of the impact of corporate governance on the East Asian financial crisis. J. Fin. Econ. 64: 215-221.

Muhajir, Ilyas dan Triyono. (2010). Faktor-Faktor yang Mempengaruhi Struktur Modal Perusahaan Manufaktur pada Bursa Efek Indonesia Periode 20052009. Jurnal Unimus. h:1-20.

Prince Acheampong, Evans Agalega \& Albert Kwabena Shibu. (2014). The Effect of Financial Leverage and Market Size on Stock Return on The Dhana Sector Exchange: Evidence From Selected Stock In The Manufacturing Sector Department of Accountancy. Journal Koforidua Polytechnic, P O Box KF981, Koforidua Ghana.

Raheem Anser, Qaisar Ali Malik. (2013). Cash Conversion Cycle and Firm' Profitability - A Study of Listed Manufacturing Companies of Pakistan. Journal of Business and Management. 8(2): h: 83-87

Sartono, Agus. (2010). Manajemen Keuangan Teori dan Aplikasi. Edisi Empat. Yogyakarta: BPFE.

Sawir, Agnes. (2009). Analisis Kinerja Keuangan dan Perencanaan Keuangan Perusahaan. Jakarta: PT. Gramedia Pustaka Utama.

Shandy, Ahmad dan Asyik, Nur Fadjrih. (2013). Pengaruh Profitabilitas dan Likuiditas Terhadap Kebijakan Deviden Kas pada Perusahaan Otomotif. Jurnal Ilmu dan Riset Akuntansi, 1(1), h: 58-76. 
Sjahrial, Lukman, (2007). Manajemen Keuangan Perusahaan Konsep Aplikasi dalam Perencanaan Pengawasan dan Pengambilan Keputusan. Jakarta: PT. Raja Grafindo Persada.

Soejoto. (2001). Pengaruh Rasio Profitabilitas dan Leverage Terhadap Terhadap Return Saham Perusahaan Manufaktur di Bursa Efek Indonesia. Jurnal. UNNES: Semarang.

Solechan, Ahmad. (2009). Pengaruh Manajemen Laba dan Earning Terhadap Return Saham (Studi Empiris pada Perusahaan Go Public di BEI Tahun 2003-2006). Tesis. Universitas Diponegoro, Semarang.

Sudarmadji, Sularto. (2007). Pengaruh Ukuran Perusahaan, Profitabilitas, dan Tipe Kepemilikan Perusahaan terhadap Luas Voluntary Disclousure Laporan Keuangan Tahunan. Jurnal Akuntansi dan Bisnis, 2 (2), hal: 149155.

Sugiyono. (2010). Metode Penelitian Bisnis. Bandung: Alfabet.

Sugiarto, Agung. (2011). Analisa Pengaruh Beta, Size Perusahaan, DER, dan PBV Ratio terhadap Return Saham. Jurnal Dinamika Akuntansi, 3(1), PP : 8-14.

Sutrisno. (2006). Manajemen Keuangan: Teori, Konsep dan Aplikasi. Yogyakarta: EKONISIA.

Ulupui, I G. K. A. (2007). Analisis Pengaruh Rasio Likuiditas, Leverage, Aktivitas, dan Profitabilitas Terhadap Return Saham (Studi Pada Perusahaan Makanan dan Minuman dengan Kategori Industri Barang Konsumsi di BEJ), AUDI Jurnal Akuntansi dan bisnis, Vol.2, No. 1.

Wiagustini. Ni Luh Putu. (2010). Dasar-dasar Manajemen Keuangan. Denpasar: Udayana University Press.

Wibawa, Oka Surya IB. (2015). Pengaruh Rentabilitas dan Leverage pada Saham Bonus di Perusahaan yang Terdaftar di BEI periode 2000-2014. Jurnal Ekonomi,Bisnis dan Akuntansi, 16 (2), hal: 1433-1460.

Wimelda, Linda, dan Marlinah, Aan. 2013. Variabel-Variabel yang Mempengaruhi Struktur Modal pada Perusahaan Publik Sektor Non Keuangan. Media Bisnis. Pp: 200-213.

Yuliantari dan Sujana, I Ketut. (2014). Pengaruh Financial Ratio, Firn Size, Dan Cash Flow Operating Terhadap Return Share Perusahaan F\&B. Jurnal Akuntansi dan Bisnis. Universitas Udayana. 